\title{
The Arnold Berliner Award 2017
}

\author{
Sven Thatje ${ }^{1}$
}

Received: 23 June 2017 / Accepted: 25 June 2017 / Published online: 5 July 2017

(C) Springer-Verlag GmbH Germany 2017

The recipient of this year's Arnold Berliner Award (Thatje 2013) is Mr. Deni Purwandana (Komodo Survival Program, Bali, Indonesia, Fig. 1), in recognition of his research article on the Komodo dragon (Varanus komodoensis) published in The Science of Nature in 2016 (Purwandana et al. 2016). The study is a contribution to the Komodo Survival Program, a long-term protection programme of this enigmatic lizard.

In his study, Purwandana and collaborators focused on ontogenetic changes in feeding habits, including prey size, and the use of landscape as part of the ecological niche in the Komodo dragon. The study was conducted in the Komodo National Park in Eastern Indonesia, which consists of a series of islands including the two most substantial islands, Komodo and Rinca, between 2002 and 2015. Komodo dragons live up to 60 years and can reach a body weight of $90 \mathrm{~kg}$. The study demonstrated that the Komodo dragon changes its prey size preferences and the use of its ecological niche with age and size. A sudden and dramatic shift in prey size from small $(\leq 10 \mathrm{~kg})$ to large prey $(\geq 50 \mathrm{~kg})$ is observed in lizards heavier than $20 \mathrm{~kg}$. When weighing $20 \mathrm{~kg}$ and more, the lizards shift their feeding ethology from a highly active foraging strategy exploring small prey to a less active sit-and-wait feeding strategy, with the aim to hunt large ungulates.

These ontogenetic changes in hunting behaviours are accompanied by marked changes in their ecological niche,

Communicated by: Sven Thatje

Sven Thatje

sthatje@icloud.com

1 Ocean and Earth Science, University of Southampton, National Oceanography Centre Southampton, European Way, Southampton SO14 3ZH, UK meaning changes in the landscapes used. By changing its ecological niche preference, the Komodo dragon can exploit prey across multiple trophic levels, avoids direct competition between lizard size classes, and optimises the use of limited resources in an island habitat. Given the observed changes throughout ontogeny in this species, it is most likely that the larger Komodo dragons do possess a more efficient pattern of energy use, as their hunting strategy is highly specialised.

The Arnold Berliner Award was established in recognition of the founding editor of Naturwissenschaften (now The Science of Nature, Thatje 2013) who led the journal for the lengthy period of 22 years. The award is sponsored by

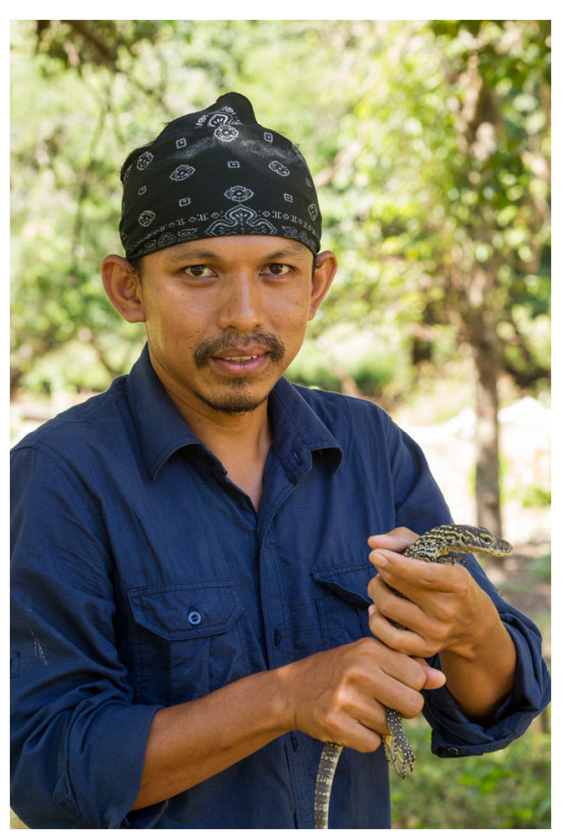

Fig. 1 Deni Purwandana, winner of the Arnold Berliner Award 2017 (photo credit: Nicolas Cegalebra) 


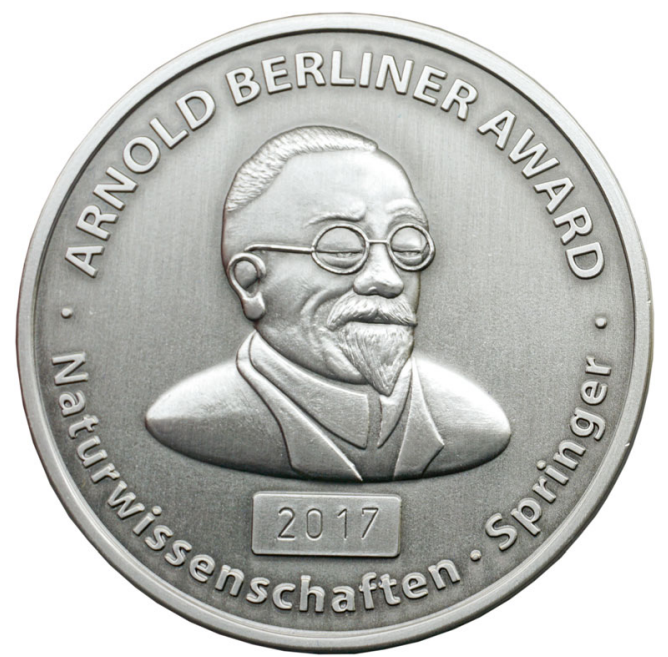

Fig. 2 The Arnold Berliner Award Medal. Arnold Berliner (1862-1942) was the founding editor of The Science of Nature and the journal's editorin-chief from 1913 to 1935 (Thatje 2012, 2013)

Springer and is given annually for the best research article published in The Science of Nature during the previous calendar year (Thatje 2012). Criteria are excellence in science, originality, as well as aspects of interdisciplinarity, overall mirroring Arnold Berliner's motivation for initiating the journal. A jury, consisting of the board of editors and the editor-inchief, selects the awardee. The award is marked with the Arnold Berliner Award Medal (Fig. 2) and is accompanied by a biennial subscription to the electronic edition of The Science of Nature, a 500-euro voucher for Springer books, as well as a cash prize of 250 euros.

\section{References}

Purwandana D, Ariefiandy A, Imansyah MJ, Seno A, Ciofi C, Letnic M, Jessop TS (2016) Ecological allometries and niche use dynamics across Komodo dragon ontogeny. Sci Nat 103:27. doi:10.1007/ s00114-016-1351-6

Thatje S (2012) Introducing the Arnold Berliner Award. Naturwissenschaften 99(9):675-676

Thatje S (2013) Dr Arnold Berliner (1862-1942), physicist and founding editor of Naturwissenschaften. Naturwissenschaften 100:11051107 